\title{
Determinants of Anti-Corruption Disclosure in State-Owned Enterprise in Indonesia
}

\author{
Miftahul Jannah, Desi Adhariani* \\ Department of Accounting, Faculty of Economics and Business, Universitas Indonesia \\ ${ }^{*}$ Corresponding author. Email: desi.adhariani@ui.ac.id
}

\begin{abstract}
Corruption within corporations has become an important issue in academic and public debate. This study examines the impact of political connections and the gender of executives on anti-corruption disclosures (ACD). Using a sample of 29 state-owned enterprises (SOEs) listed on the BEI (Indonesia Stock Exchange) from 2015 to 2017, we ran a multiple regression analysis that shows political connections negatively affect ACD. The findings also show that executive gender, specifically having women on the boards of SOEs in Indonesia, does not affect the impact of political connections on ACD. This research makes an important contribution to the literature by developing and empirically testing the study of anti-corruption disclosure within legitimacy theory.
\end{abstract}

Keywords: Political Connection, Executive Gender, Anti-Corruption, Legitimacy Theory

\section{INTRODUCTION}

Corruption has become a major problem in many countries, including Indonesia. Acts of corruption affect many macro-level aspects of a country, including political, economic, social and cultural. These macrolevel effects can lead to a worsening of conditions in a country's business activities. For these reasons, the world has taken steps to combat corruption, one of which was the establishment of United Nations Convention Against Corruption in 2003. Indonesia, one of the largest countries by population in the world, has shown its commitment to the U.N. anti-corruption efforts by ratifying the UNCAC through Indonesian Law (UU) No. 2006.

Transparency International, an international nongovernmental organization, publishes a Corruption Perception Index (CPI) that measures and ranks 180 countries and territories by their perceived levels of public sector corruption. Based on this CPI in 2018, Indonesia ranks $89^{\text {th }}(1=$ least corrupt $)$. This rank has improved from the preceding year, when Indonesia was ranked $96^{\text {th }}$. When measured by region, Indonesia was in fourth place in Southeast Asia after Singapore, Brunei Darussalam, and Malaysia. At the micro-level, Transparency International requires every company in a country to support anti-corruption acts. Joseph et al. (2015) found that due to limited Corporate Social Responsibility (CSR) research on corruption issues, researchers could use anti-corruption information disclosures in a company's annual reports to understand the company's commitment to combatting corruption.

This study investigates the use of anti-corruption disclosures and their determinants in a specific context, namely state-owned enterprises in Indonesia. This specific context has rarely been studied; hence, this study can make an important contribution to filling this gap in the literature. This research can also make a practical contribution by providing suggestions to improve anti-corruption efforts in state-owned enterprises. The remainder of this paper is organized as follows. In Section 2 we present a literature review. In Section 3, we explain our theoretical framework and research methodology, in Section 4 we provide the analysis of results, in Section 5 we offer conclusions, and in Section 6 we present limitations of the research.

\section{LITERATURE REVIEW}

\subsection{Anti-Corruption Disclosure}

Corruption is defined as the abuse of entrusted power for personal gain (Transparency International, 2015). In Indonesia, a number of laws and regulations have been established to encourage anti-corruption programs, and academic researchers have studied anticorruption disclosures in different countries around the world. Saenz and Brown (2018) studied anti-corruption 
disclosures in construction companies with samples consisting of 10 Latin American countries and 16 other countries using an AMQ (Anti-corruption Model Questionnaire), focusing on Leadership and Commitment, Control and Evaluation, Planning, and Implementation. The anti-corruption indicators used in the study were GRI G4, GRI 205, ISO 26000 in 2010, and ISO 37001 in 2016. Results show the fewest disclosures on the topic of implementation. Saenz and Brown (2018) found ISO 37001 to be the most complete in terms of anti-corruption disclosures, yet it is still focused on bribery aspects.

\subsection{Political Connection}

Political connection is a global phenomenon that leads to corruption (Pan and Tian, 2017). Faccio (2006) revealed that governments are more likely to "bail out" companies facing financial difficulties if they have political connections. Some studies show that companies with political connections pay less attention to financial reporting quality and governance (Qian et al., 2011; and Chaney 2011). Pan and Tian (2017) conducted research after a corruption scandal in China. They showed that after politicians are expelled from companies, especially from non-SOE companies, those companies become more efficient in terms of investment, and bribery levels are lower after anticorruption campaigns by politicians. Zhang et al. (2010) state that anti-corruption policies are more effectively applied to companies connected to the government. Zhang et al. (2010) found that bankers are often forced to provide loans for projects carried out by companies with political connections, even though the projects are estimated to be unprofitable. Based on this body of research, we develop the following hypothesis:

\section{H1: Political connections negatively affect the level of} anti-corruption disclosures

\subsection{State-control perspective of State-Owned Enterprises (SOEs)}

Liang et al., (2015) conducted a study to integrate agency theory with institutional analysis in international business regarding government-control mechanisms in emerging economies' globalization of state-owned enterprises (SOEs), by considering the following two types of state control over SOEs: state control to influence SOEs' decision to pursue globalization, and the degree of globalization. They found that state control has a strong effect on SOEs' decisions to pursue globalization. They also found a diminishing impact of SOEs' executives' political connections as state ownership increased control of SOE firms.

\subsection{Legitimacy Theory}

In general, companies are responsible for informing its stakeholders about its social impact and governance (Cho et al., 2015). Legitimacy theory explains that an organization, in carrying out its operational activities, must show behavior that is consistent with social values (Guthrie and Parker, 2006). Muttakin et al., (2015) conducted a study that linked political connections to CSR Disclosure in Bangladesh, as one of the countries with a high level of corruption. This research shows that political connections are inversely associated with CSR disclosure, based on findings of research from the annual reports of 936 firms listed in the Dhaka Stock Exchange during year 2005 to 2013.

\subsection{Executive Gender}

While discussing gender-related discrimination in a professional workplace is not uncommon, studying its effect on anti-corruption cases may bring an interesting new perspective to the understanding of anti-corruption programs implemented by companies. Previous research has revealed the influence of gender on financial decisions. Ernst and Young (2009) found that groups with greater gender diversity tend to have better financial performance than homogeneous groups, even if those groups include more experienced people.

\subsection{Gender Socialization Theory}

Gender socialization theory argues that since there are differences between men and women, their behaviors will differ, reflecting differences in their values, ethics, and attitudes. The reason for this phenomenon is that behavior is strongly influenced by education and is reinforced by social norms (Dawson 1992; Gilligan 1982 in Harris et al. (2019). Some accounting research, including Shawver et al. (2006), show that women engage in bribery and fraud less frequently than men. This is in line with Barua et al. (2010) who find that women will be more accrual in financial statements. Liao et al. (2019) studied the effect of female CFOs on accounting fraud in government companies in China. He showed superior results in companies with more balanced proportions of men and women on the board of directors. Based on these studies, we develop the following hypothesis:

H2: Having females at the executive level in firms has a negative effect on the impact of political connections to anti-corruption disclosures

\section{RESEARCH METHOD}

The data collected in this study was secondary data. Samples were obtained using the purposive sampling method based on certain criteria to produce a 
representative sample. The sample criteria that were used are as follows:

- $\quad$ The company must have published financial annual reports that were audited each year during the period 2015 to 2017, and must be listed on the BEI (Indonesia Stock Exchange).

- In the event that the annual financial statements were revised after they were originally published, the research sample is adjusted according to the revised reports issued during the period 2015 to 2017.

- Companies in the financial sector industry are excluded from the sample as their balance sheet characteristics (asset types and leverage) differ substantially from other types of companies.

- CEO profile data (if any) are taken from the financial report or obtained through the Indonesian Capital Market Directory (ICMD)

\subsection{Dependent Variable}

We used the anti-corruption index proposed by Joseph et al. (2015) as a dependent variable. The measurement of anti-corruption is carried out using the scoring method used in that study. Scores for this variable were generated by conducting a content analysis through a review of the annual report and sustainability report. The content analysis was divided into 7 general categories with a total of 40 subcategories and was measured using a dichotomous scale adopted from Dissanayake et al. (2011). Examples of the disclosure are "The company prohibits all forms of bribery whether they take place directly or through third parties" and "The company establishes feedback mechanisms and other internal processes supporting the continuous improvement of the program". In this study, we extend the sub-categories into 43 categories, focusing on assurance, verification, and internal controls in whistle-blowing arena to form a more comprehensive list of anti-corruption efforts than has been previously investigated.

\subsection{Independent Variable}

The independent variable in this study is the level of political connection. It was Faccio (2006) who stated that a company that was politically connected was a company that had a relationship with a politician, based on whether one or more of its major shareholders (at least $10 \%$ ownership), or one of its top executives is a member of parliament or has a close relationship to a politician or political party. In this study, we use a proxy based on Faccio (2006), and also a proxy from Fan (2007) which included independent commissioners as a source of political connections. Thus, the political connection variable in this study uses sub-variables, namely:
- CEOs who are members of political parties, and

- Independent commissioners who have political relations.

\subsection{Control Variables}

We use three control variables in this study to ensure that the company attributes related to profitability, financial leverage, and company size have been included in predicting anti-corruption disclosure activities. The control variables used for the research are financial leverage (Debt-to-Equity Ratio), financial profitability (ROE), and the natural log of Total Asset, representing company size.

\subsection{Research Design}

To address the first hypothesis of this study, we use the following model:

$$
\begin{gathered}
\mathrm{ACD}=\propto+\beta_{1} \mathrm{PCONi}+\beta_{2} \mathrm{GENi}+\beta_{3} \mathrm{LEVi}+ \\
\beta_{4} \text { PROFi }+\beta_{5} \text { SIZEi } \ldots .(1)
\end{gathered}
$$

Descriptions of Variables:

ACD : Anti-Corruption Disclosure (Value of anticorruption disclosure score for company $i$ in fiscal year $t$ )

PCONi : the political connection score of the executives in company $i$

GENi : dummy variable for executive gender, set $=1$ for female executives (BOD or CFO) in company $i$, and 0 for male executives in company $i$.

LEVi : financial debt divided by long-term debt plus equity (excludes other non-current liabilities) and short-term debt of company $i$.

PROFi : Profitability of company $i$

SIZEi : Log of total assets of company $i$

$\alpha \quad$ : constant value

$\beta x \quad$ : regression coefficients

The model for the second hypothesis is as follows:

$\mathrm{ACD}=\propto+\beta_{1} \mathrm{PCON} i+\beta_{2} \mathrm{GEN} i+\beta_{3}(\mathrm{PCON} i \times$

Descriptions of Variables:

ACD : Anti-Corruption Disclosure (Value of anticorruption disclosure score for company $i$ in fiscal year $t$ )

PCONi : the political connection score of the executives in company $i$

GENi : dummy variable of executive gender, set $=1$ for female executives (BOD or $\mathrm{CFO}$ ) in 
company $i$, and 0 for male executives in company $i$.

LEVi : financial debt ratio divided by the number of financial debts plus equity. Financial debt is long-term debt (excludes other non-current liabilities) plus short-term debt of company $i$.

PROFi : Profitability of company $i$

SIZEi : Log of total assets of company $i$

\subsection{Sample and Data}

Data was collected from various sources. ACD information was extracted from company annual reports. The ACD measurement was developed by Joseph et al. (2015), using the 40 anti-corruption criteria in seven subcategories. We also include three additional subcategories for ACD measurement. The 43 ACD measurements are as follow:

- Accounting disclosures on combating bribery. This consists of sub-categories such as prohibition of bribery; commitments of no direct or indirect contributions to political parties; and disclosures on political contributions.

- Disclosure on Board (BOD) and Senior Management responsibilities, such as their commitment to the company's anti-corruption policy and program, and independent assessments.

- Building human resources (HR) to combat bribery. This consists of sub-category such training employees in an anti-corruption program.

- Responsible business relationships. This consists of the following sub-categories: programs to monitor joint ventures and consortiums; remuneration of

Table I. Descriptive Statisics agents only for services rendered; transparent procurement practices; reporting the number of contracts terminated.

- Codes of conduct (CoC). This consists of the following sub-categories: Establishment of a $\mathrm{CoC}$ relating to anti-corruption that is communicated to the executive or Board member; implementation of the CoC.

- Whistle Blowing. This consists of these subcategories: whistle blowing policy; implementation; verification or assurance of whistleblowing policy; disclosure of the external review.

\section{RESULT}

We used 36 SOE companies listed on the BEI (Indonesia Stock Exchange) during the period 2015 to 2017 as our sample. From a total of 36 firms, we exclude seven firms due to a negative ROE that might cause abnormal or outlier results.

The final sample comprises the remaining 29 firmyears. Table I provides descriptive statistics for the sample data. The minimum ACD score is 0.1163 , while the maximum score is 0.6744 . Therefore, the average ACD for SOEs in Indonesia from 2015 to 2017 is 0.3937, which indicates that anti-corruption disclosure for SOE companies is still below the median score of $0.50 .22 \%$ of the sample are politically connected firms (PCON), and $13.8 \%$ of them have female executives (CEO/CFO/other Board members) - (GEN). The average level of profitability (ROE) is approximately $12 \%$, and the average level of leverage (LEV) is approximately $1.31 \%$.

\begin{tabular}{|c|c|c|c|c|c|c|}
\hline NO & Variable & Obs & Mean & Std. Dev. & Min & Max \\
\hline 1 & ACD & 29 & 0.3937 & 0.1538 & 0.1163 & 0.6744 \\
\hline 2 & PCON & 29 & 0.4483 & 0.5061 & 0.0000 & 1.0000 \\
\hline 3 & GEN & 29 & 0.1379 & 0.3509 & 0.0000 & 1.0000 \\
\hline 4 & LEV & 29 & 1.3110 & 0.8807 & 0.3900 & 3.8300 \\
\hline 5 & PROF & 29 & 12.0293 & 8.8387 & 0.3500 & 32.9500 \\
\hline 6 & SIZE & 29 & 17.0903 & 1.1741 & 14.2432 & 19.1062 \\
\hline
\end{tabular}

\subsection{Analysis}

Table II presents the results of the regression models. Political connection (PCON) has a significantly negative impact on anti-corruption disclosure (ACD) with a p-value of 0.0080 . However, we find that having female executives (GEN) does not have a significant effect on anti-corruption disclosure (ACD), with a p- value of 0.6990 . We also found that among the control variables, only the Profitability variable (PROF) has a significant (negative) effect, on anti-corruption disclosure (ACD) with a p-value of 0.0010 . This result indicates that a firm with political connections has a lower level of anti-corruption disclosure, which is consistent with our first hypothesis. 
Table II. Regression Model Result

\begin{tabular}{|l|l|l|l|l|}
\hline No. & Variable & Predicted Effect to Variable ACD & Coefficient & Prob. \\
\hline 1 & PCON & - & -0.1471 & 0.0080 \\
\hline 2 & GEN & - & -0.0253 & 0.6990 \\
\hline 3 & LEV & + & 0.0231 & 0.3950 \\
\hline 4 & PROF & - & -0.0112 & 0.0010 \\
\hline 5 & SIZE & - & -0.0072 & 0.7460 \\
\hline
\end{tabular}

Table III presents the result of having one or more female executives in the company as a moderating variable that could affect the negative effect of political connection on anti-corruption disclosures for in SOEs in Indonesia. The result of this regression, as shown in table III, indicates that female executives (GEN) do reduce the negative effect of political connections
(PCON) on anti-corruption disclosure activities (ACD). However, the result is far from significant. The $p$-value for how female executives might affect political connections' negative impact on anti-corruption disclosure is 0.520 , which is much greater than the 0.05 confidence level required to be confident in the relationship between the variable and the outcome.

Table III. Moderating Affect

\begin{tabular}{|l|l|l|l|l|}
\hline No. & Variable & Predicted Affect to Variable ACD & Coefficient & Prob. \\
\hline 1 & PCON & - & -0.1364 & 0.0190 \\
\hline 2 & GEN & + & 0.0211 & 0.8290 \\
\hline 3 & PCON with GEN (Moderating Variable) & - & -0.0992 & 0.5200 \\
\hline 4 & LEV & - & 0.0211 & 0.4440 \\
\hline 5 & PROF & - & -0.0104 & 0.0030 \\
\hline 6 & SIZE & - & -0.0147 & 0.5640 \\
\hline
\end{tabular}

\section{DISCUSSION AND CONCLUSION}

The empirical evidence from SOE companies listed on the Indonesia Stock Exchange supports our hypothesis that political connections may be associated with a reduced commitment to anti-corruption disclosure in a company's financial reports. The results also show that firms need anti-corruption disclosure to address stakeholder pressure. This is consistent with Muttakin et al. (2015) who claim that firms can use political connections to manage stakeholder pressure. The results have implications for expanding findings of prior studies that drew up political connection as a legitimacy strategy (e.g., Deegan, 2010; Woodward et al., 1996; Muttakin et al.,2015).

This study also reports that executive gender was not influential in the relationship between political connections and anti-corruption disclosure. This finding differs from Hao (2017) who finds that a higher ratio of women in the labor force is associated with a lower corruption rate. Nonetheless, we can refer to Liang et al., (2015) who found the strong control mechanism of government in influencing SOEs' business decisions reduced the impact of SOEs' executive political connections. In this regard, Liang et al., (2015) could explain our result that executive gender does not moderate the relationship between political connections and anti-corruption disclosure.

\section{RESEARCH LIMITATIONS}

This study has several limitations that need to be considered in future research, including:

- Our dataset is limited to SOEs listed on the Indonesia Stock Exchange during the period 20152017. Therefore, the number of firms in the sample was quite limited.

- Using a larger number of companies may show a different result, because in addition to the benefits of larger sample sizes with respect to data variations, including different types of organization and different industries would better 
capture the full array of political connections and anti-corruption disclosures.

- $\quad$ Future research could use a longer research period, instead of the three-year period used in this study.

\section{REFERENCES}

[1] Deegan, C., Rankin, M. and Tobin, J. (2002) 'An examination of the corporate social and environmental disclosures of BHP from 19831997: a test of legitimacy theory', Accounting, Auditing \& Accountability Journal, 15(3), 312-343.

[2] Dissanayake, T. M., Azizul Islam, and Steven, D. (2011) 'Corporate Disclosure on Combatting Bribery: A Study of Two Global Companies in the Telecommunication Industry." Conference on Social and Environmental Accounting Research (CSEAR). Australia: University of Tasmania.

[3] Ernst \& Young. (2009) Ground breakers study, diversity an equation for success

[4] Faccio, M. (2006) 'Politically connected firms'. The American Economic Review 96(1 ) 369-389.

[5] Faccio, M., Masulis, R.W., and McConnell, J.J., (2006) Political connections and corporate bailouts. The Journal of Finance 61, 2597-2635.

[6] Fan, J.P.H., Wong, T.J., and Zhang, T., 2007. 'Politically connected CEOs, corporate governance, and post-IPO performance of China's newly partially privatized firms'. Journal of Financial Economics 84, 330-357.

[7] Fisman, R. (2001) 'Estimating the value of political connections'. American Economic Review 91, 1095-1102.
[8] Guthrie, J., and Parker, L. D. (1989) 'Corporate social reporting: a rebuttal of legitimacy theory'. Accounting and Bussiness Research, Vol. 19 No. 7, pp. 343-352.

[9] Hao, Y., Chang, C-P., and Sun, Z. (2017). Women and Corruption: evidence from multinational panel data, Springer Science+Business Media B.V.

[10] Joseph, C., Gunawan, J., Sawani, Y., Rahmat, M., Noyem, J. A., \& Darus, F. (2016) 'A comparative study of anti-corruption practice disclosure among Malaysian and Indonesian Corporate Social Responsibility (CSR) best practice companies'. Journal of cleaner production, 112, 2896-2906.

[11] Liang, H., Ren, B., and Sun, S. L. (2014). An anatomy of state control in the globalization of state-owned enterprises, Journal of International Business Studies, 46, 223-240.

[12] Liao, J., Smith, D., and Liu, X. (2019) 'Female CFO and accounting fraud: evidence from China'. Pacific-Basin Finance Journal 53 449-463

[13] Muttakin, B., Mihret, G., Khan, A. (2018) 'Corporate political connection and corporate social responsibility disclosures'. Accounting, Auditing \& Accountability Journal 31, 2.

[14] Transparency International, (2015). Archive Link. Retrieved from: http://archive.transparency.org/news_room/faq/corr uption_faq

[15] Woodward, D.G., Edwards, P., and Birkin, F. (1996) Organizational legitimacy and stakeholder information provision. British Journal of Management, 7 (4), 329-347. 